\title{
SPATIAL AND TEMPORAL VARIATIONS IN ELECTRICAL CONDUCTIVITY IN A PRO-GLACIAL STREAM SYSTEM
}

\author{
By A. M. GURNELL \\ (Department of Geography, University of Southampton, Southampton SO9 5NH, England) \\ and $\mathrm{C}$. R. FENN
}

(Department of Geography, Worcester College of Higher Education, Henwick Grove, Worcester WR2 6AJ, England)

ABstract. Spatial and temporal observations of electrical conductivity during the summers of 1978 and 1981 on the pro-glacial stream sytem of glacier de Tsidjiore Nouve, Valais, Switzerland, are described. Three space-time scales of electrical conductivity variations are considered: single-site, hourly monitoring for a two-month period; multiple-site sampling over $12 \mathrm{~h}$ periods using a $1 \mathrm{~h}$ sampling interval, and multiple-site sampling over monthly periods using a $24 \mathrm{~h}$ and $48 \mathrm{~h}$ sampling interval. Detailed analysis of the information from the three scales shows that the sampling strategies employed can reliably be used to investigate space-time patterns in the data. The results demonstrate that there are diurnal cycles in both electrical conductivity and discharge which are slightly different in form and which are out of phase with one another at the same site. Simultaneous multiple-site sampling of electrical conductivity shows that the tributary streams draining the glacier snout exhibit complementary shifts in electrical conductivity between ablation seasons, between days, and within days. The significance of these complementary shifts in tributary electrical conductivity are discussed in the light of possible source areas, storage, and routing fluctuations of melt water draining from the glacier.

RÉsumé. Variations spatio-temporelles de la conductivité électrique dans un système d'émissaires proglaciaires. On dècrit les observations spatio-temporelles de conductivité électrique au cours des étés 1978 et 1981 sur le système d'écoulement proglaciaire du glacier de Tsidjiore Nouve, Valais, Suisse. On envisage trois échelles de variations spatio-temporelies pour la conductivité électrique: un site unique avec un échantillonnage horaire sur une période de deux mois; un échantillonnage de sites multiples sur des périodes de $12 \mathrm{~h}$ avec des intervalles horaires de mesures et enfíin un échantillonnage de sites multiples sur des périodes mensuelles avec cles intervalles de mesures de 24 at $48 \mathrm{~h}$. Une analyse détaillée des informations données par les trois échelles montre que la stratégie d'échantillonnage utilisée se révèle fidèle pour recherer des caractéristiques de distribution

\section{INTRODUCTION}

The concentration of solutes in glacial melt water reflects the water's initial source area, the route it has taken through the glacier from that source, and the degree and time of melt-water-moraine contact (Lemmens, 1978). Several researchers have noted that glacial basal ice and waters may be solute rich (Souchez and others, 1973, 1978; Vivian and Zumstein, 1973; Souchez and Lorrain, 1975) and that supraglacial melt water has a low solute concentration (Collins, 1979). Collins (1979) and Oerter and others (1978) have also spatio-tempcrelles. Les résultats montrent l'existence de cycles diurnes à la fois dans la conductivité électrique et le débit de forme légèrement différente, en opposition de phase au même site. Des échantillonnages simultanés en divers sites montrent des caractéristiques de conductivité complémentaires, entre les périodes d'ablation, les mêmes jours, ou de jour en jour. La signification de ces traits complémentaires dans la conductivité des émissaires est discutée dans l'hypothèse des zones sources possibles et des fluctuations dans la rétention et le parcours de l'eau de fonte à travers le glacier.

ZuSAMMENFAssuNG. Räumliche und zeitliche
Schwankungen der elektrischen Leitfähigkeit eines
Stromsystems in Gletschervorfeld. Es werden räumliche
und zeitliche Beobachtungen der elektrischen
Leitfähigkeit im Stromsystem des Vorfeldes des Glacier
de Tsidjiore Nouve, Wallis, Schweiz, in den
Sommermonaten der Jahre 1978 und 1981 beschrieben.
Drei raum-zeitliche Skalen für Schwankungen der
elektrischen Leitfähigkeit werden betrachtet: stündliche
Aufzeichnungen an einer Stelle über eine Periode von 2
Monaten, Datensammlungen über Monatsperioden im 24-
und 48-Stunden-Rhythmus an mehreren Stellen und
schliesslich Datensammlung in Perioden von 12 Stunden
im 1-Stunden-Rhythmus an mehreren Stellen. Die
eingehende Analyse der Daten aus den drei Skalen zeigt,
dass das angewandte Beobachtungsverfahren zu
zuverlässigen Aufschlüssen über die raum-zeitlichen
Verhältnisse führt. Die Ergebniss weisen Tageszyklen
sowohl der elektrischen Leitfähigkeit wie des Abflusses
nach, deren Formen leicht voneinander abweichen und
die sich an derselben Stelle nicht in gleicher Phase
befinden. Gleichzeitige Beobachtungen der elektrischen
Leitfähigkeit an mehren Stellen zeigen, dass die
Nebenstöme aus der Gletscherzunge komplementäre
Schwankungen der elektrischen Leitfähigkeit zwischen
Ablationsperioden sowie zwischen und innerhalf von
Tagen aufweisen. Die Bedeutung dieser komplementären
Schwankungen in der elektrischen Leitfähigkeit der
Nebenströme wird unter dem Aspekt der möglichen
Herkunftsgebiete, der Speicherung und der Schwankungen
im Schmelzwasserabfluss vom Gletscher diskutiert.

shown that continuous monitoring of electrical conductivity and discharge of glacial melt water near to the snout of a glacier can form a basis for separating rapidly draining melt water without significant chemical enrichment from delayed, chemically enriched water, including ground water. Collins (1979) termed these "englacial" and "subglacial" flow contributions respectively, and formalized a simple two-component mixing model to explain temporal variations in the quantity and quality of bulk melt waters emerging from a glacier. Raiswell (1984) has recently presented chemical models capable of explaining the hydrochemical 
evolution of the two components in terms of their open-system (englacial) and closed-system (subglacial) characteristics.

Previous studies of the electrical conductivity of pro-glacial streams have invariably concentrated on temporal variations observed at single sites. It is contended here that information on joint space-time variations in electrical conductivity is important in relation to the identification of the sources, flow routes, and flow rates of glacial outflow waters, and also in relation to the determination of the nature and extent of spatial variation in solute concentrations in glacier basins. The latter aspect has so far received little attention, apart from some brief reports on variations in electrical conductivity along pro-glacial streams (Lemmens and Roger, 1978, and in discussion of Metcalf, 1979). The present paper examines space-time variations of electrical conductivity measured at multiple sites on the pro-glacial stream network of glacier de Tsidjiore Nouve, Valais, Switzerland. Three space-time scales of electrical conductivity variations are considered: single-site variations at $1 \mathrm{~h}$ intervals over two months; multiple-site variations at $1 \mathrm{~h}$ intervals over $12 \mathrm{~h}$ periods; and multiple-site variations at $24 \mathrm{~h}$ and $48 \mathrm{~h}$ intervals over monthly periods.

\section{FIELD AREA AND METHODS}

Melt water from glacier de Tsidjiore Nouve is collected as part of a hydro-electric power scheme developed by Grande Dixence S.A. The water intake is located approximately $360 \mathrm{~m}$ from the glacier snout and serves as a flow-gauging station with a catchment area of $4.8 \mathrm{~km}^{2}$. Eleven sites were established on the pro-glacial stream network above the water intake and main monitoring station (Fig. 1) in order to study spatial and temporal variations in the electrical conductivity of the pro-glacial run-off. In practice, at a given time, the electrical conductivity was found to be invariant along the main channel once water from the tributary streams was completely mixed (a maximum difference of $0.5 \mu \mathrm{S} \mathrm{cm}{ }^{-1}$ was found between site 3 and the water intake for simultaneous sampling), and so there will be no discussion here of results from the main channel sites 2 to 5 inclusive. Observations at site 1 (1981) and at the intake and the main monitoring station (1978) will be used to represent the electrical conductivity in the main channel and will be compared with observations from sites 6 to 11 on tributary streams to the main channel.

In order to facilitate the examination of patterns in electrical conductivity at a range of spatial and temporal scales, water samples were collected from the sites identified in Figure 1 through the following sampling schemes:

(1) Continuous records of electrical conductivity and discharge were collected at the water intake from $14.00 \mathrm{~h}$ on 6 June to $24.00 \mathrm{~h}$ on 30 July 1978 and a series of hourly instantaneous values of electrical conductivity and discharge were abstracted for further analysis. Malfunctioning of the instrumentation precluded the collection of similar records in 1981 .

(2) Hour-to-hour spatial patterns of electrical conductivity were monitored by hand sampling over $12 \mathrm{~h}$ periods at sites $7,8,9$, and 1 on four days during July 1981.

(3) Day-to-day trends in the spatial pattern of conductivity were monitored by hand sampling from the main stream (sites 1 to 5 ) and from the tributary outflow streams (sites $6,7,8,9,10$, and 11) at 13.00 h on alternate days throughout July 1981 and by sampling at the main monitoring station and on the tributary streams (sites 6, 7, 8, and 9) at $11.00 \mathrm{~h}$ every day throughout July 1978.

(4) Suspended-sediment concentration was also monitored at all of the sites and time scales; the results have



Fig. 1. The pro-glacial stream network of glacier de Tsidjiore Nouve showing the locations of the sampling sites.

been presented in Gurnell (1982) and Gurnell and Fenn (1984[a]). Information on suspended-sediment concentration will only be included in the present paper where it is pertinent to the discussion of the pattern in electrical conductivity.

Hand sampling was achieved by collecting water samples in polypropylene bottles from the stream thalweg, starting with the up-stream sites and working down-stream. The time taken to sample all of the sites was kept as short as possible so that the samples could be viewed as having been simultaneously collected. The electrical conductivity of the unfiltered samples was determined in the order of sample collection as soon as all of the samples had been collected. The maximum temperature of the water samples at the time of electrical conductivity determination was $2^{\circ} \mathrm{C}$, and so 
correction of electrical conductivity to a fixed temperature was thought to be unnecessary; the uncorrected observations will be presented here. When compared with one another, these observations may be subject to an approximate $4 \%$ error as a result of differences in water temperature. Continuous monitoring of electrical conductivity was achieved within the water intake with a probe fixed near to the centre of the flow and well beneath the water surface. The continuous observations also were not corrected to a fixed temperature.

Although measurements of discharge at all of the sampling sites would have made a substantial contribution to the interpretation of electrical conductivity variations, such measurements were deemed to be logistically impossible to undertake. Moreover, given the highly turbulent and shifting bed characteristics typical of pro-glacial streams (Fahnestock, 1963; Østrem, [ $\left.\left.{ }^{c} 1975\right]\right)$, velocity-area gauging techniques are invariably less than accurate as well as time consuming, while dilution gauging was considered unsuitable given an interest in conductivity characteristics. Continuous measurements of discharge from the Tsidjiore Nouve gauging structure at the water intake were, therefore, the only flow records available. Visual observations of relative flow levels in the tributary streams were, however, also noted in the field in order to provide an indication of relative stream-flow in the tributaries.

\section{RESULTS}

Results from the measurement schemes described above are presented as follows: (i) Hourly instantaneous monitoring at the water intake.

(ii) Spatial sampling: $1 \mathrm{~h}$ sampling interval.

(iii) Spatial sampling: $24 \mathrm{~h}$ and $48 \mathrm{~h}$ sampling interval.

Hourly instantaneous monitoring at the water intake

Figure 2 shows the time series of hourly instantaneous discharge and electrical conductivity measured at the water intake from 7 June to $30 \mathrm{July}$ elsewhere in the Alps during the summer ablation period (Behrens and others, 1971; Collins, 1979). There were ablation-related, diurnal discharge cycles, particularly after 10 July, and approximately inverse diurnal cycles in electrical conductivity similar to those observed in other pro-glacial streams (Oerter and others, 1978; Collins, 1979) are also clearly discernible. Nevertheless, it is evident that the diurnal rhythm was missing or heavily damped throughout most of June and early July as a consequence of a high residual winter snow-cover on the glacier and additional summer snow-fall events causing flow recession periods from 16 to 19 June, from 24 to 27 June, and from 4 to 9 July.

The bivariate relationship between flow discharge and electrical conductivity (Fig. 3) displays the familiar inverse tendency. Collins (1979) has explained the inverse relationship between discharge and electrical conductivity in terms of the mixing of solute enriched, subglacially routed water and relatively solute-free, englacially routed water. For the Gornera, the mixing ratios have been shown to be so variable on both diurnal and seasonal time scales that joint values of discharge and electrical conductivity may be demonstrably better described by

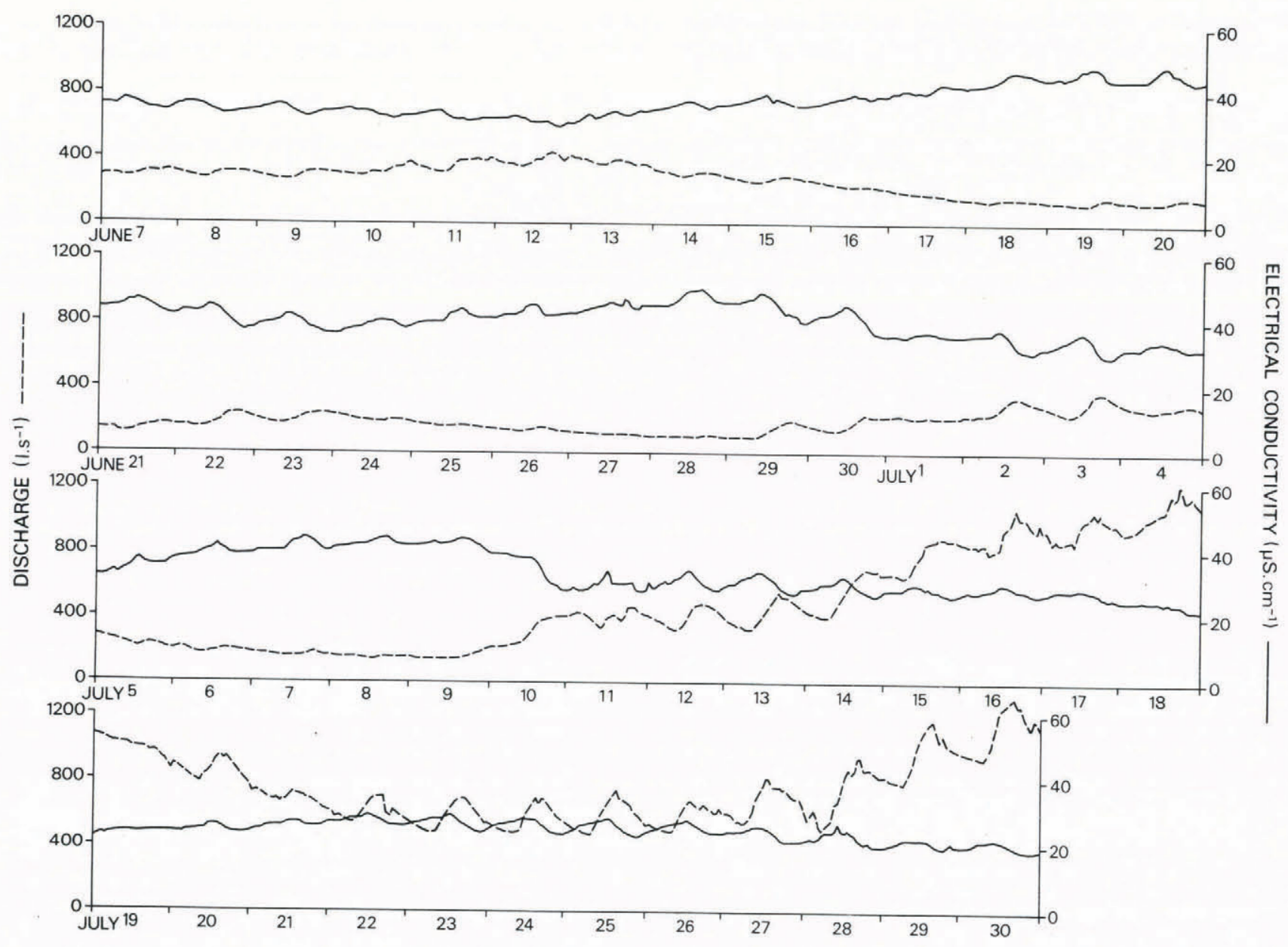

Fig. 2. Hourly instantaneous observations of discharge and electrical conductivity measured at the water intake, $1.00 \mathrm{~h} 7 \mathrm{June}$ to $24.00 \mathrm{~h} 30$ July 1978. 
TSIDJIORE NOUVE

HOURL $Y$ VAL JES

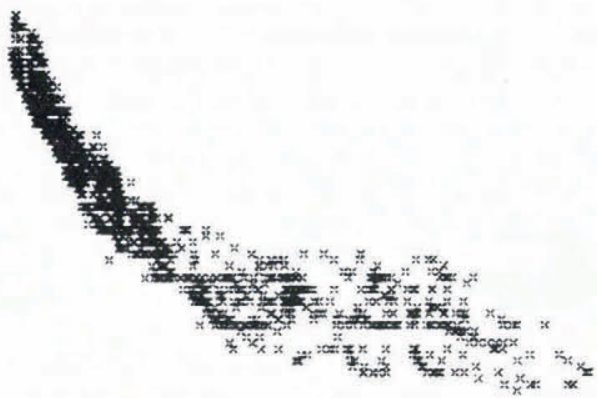

Fig. 3. The relationship between electrical conductivity and concurrent discharge observed at the water intake.

the margins of a trapezium than by a straight line, such is the range of solute concentrations which may be associated with a given discharge (Collins, 1979). The Tsidjiore Nouve data, in contrast, display a relatively well-defined pattern, indicating a more conservative relationship between variations in stream-flow and electrical conductivity than that reported for the Gornera. The relationship between electrical conductivity $(v)$ and discharge $(Q)$ presented in Figure 3 is markedly non-linear, suggesting either the flushing of solutes at high flows (in association with the extension and/or re-organization of the subglacial drainage system across fresh zones of rock debris) or the enhanced acquisition of extra solutes at low flows (in association with longer melt-water-moraine contact times).

Quantitative analysis of the relationship between electrical conductivity and discharge reveals further noteworthy features of the Tsidjiore Nouve data. A rating model of the form $\sigma=a-b \log _{10} Q$ (derived by regression analysis where $a$ and $b$ are constants) achieved a coefficient of determination of 0.91 , but yielded highly autocorrelated residuals (Durbin Watson statistic $=0.08, n=1307)$, indicating more than a simple linear relationship between the two time series. The cross-correlation function of the two data series after first differencing (Figure 4, differencing was applied to remove the trend between the series, so highlighting other characteristics) shows that the diurnal cycles in the two time series are out of phase with one another and are rather different in form. Peaks of positive correlation between the two series occur when discharge is lagged by $+15 \mathrm{~h}$ and -6 to $-7 \mathrm{~h}$ in relation to conductivity, and peaks of inverse correlation (with discharge peaks associated with conductivity "troughs") are achieved by either $a+2 h$ or $-21 \mathrm{~h}$ lag of the discharge series, with a secondary peak also occurring at $+4 \mathrm{~h}$. The best (inverse) match position occurs at $+2 \mathrm{~h}$ and there is a clear $24 \mathrm{~h}$ periodicity in the cross-correlation function.

As a result of the high cross correlation between the two time series, a Box-Jenkins transfer function (Box and Jenkins, 1970) was preferred to a simple regression model as a means of summarizing the relationship between the two series. The transfer function which best represented the relationship between the two time series was found to be:

$$
\begin{aligned}
\sigma_{t}-\sigma_{t-1} & =-8.350\left(\log _{10} Q_{t-1}-\log _{10} Q_{t-2}\right)+ \\
& +0.762\left(\sigma_{t-1}-\sigma_{t-2}\right) .
\end{aligned}
$$
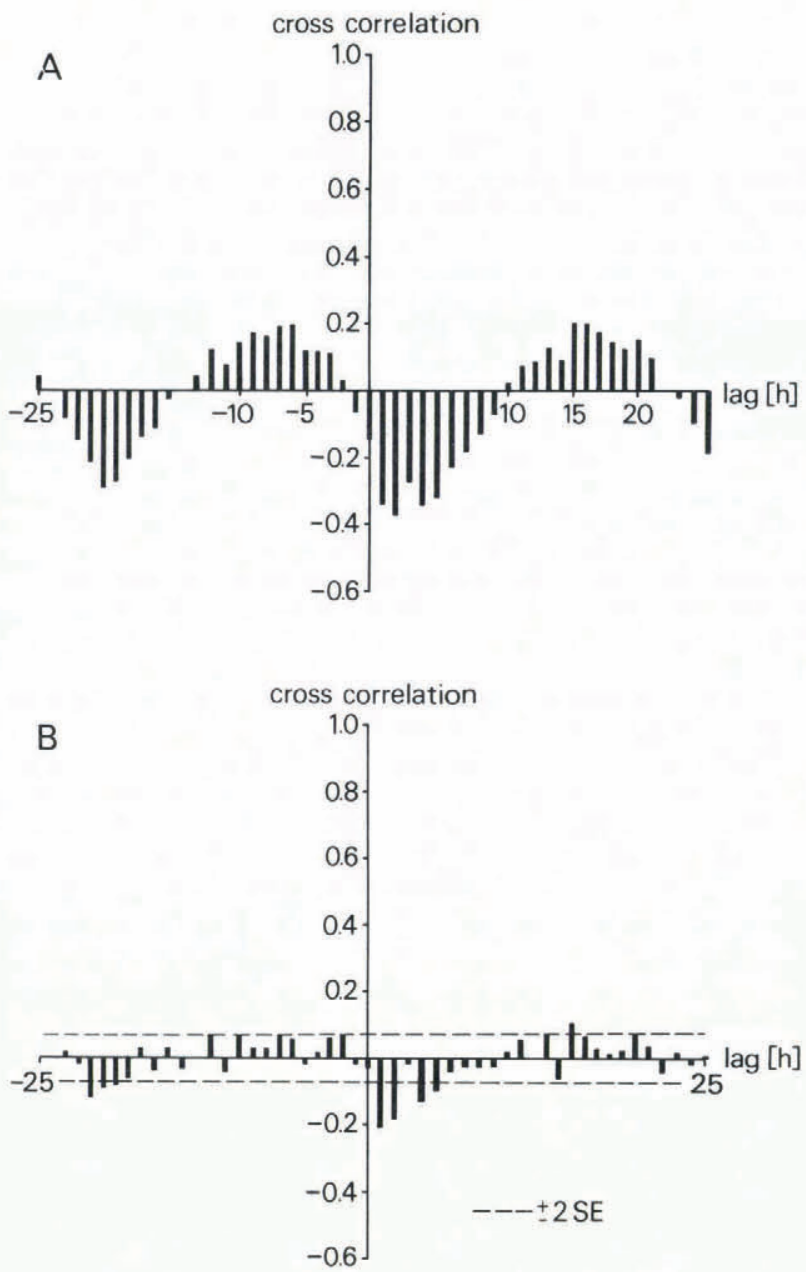

Fig. 4. The cross-correlation function between the $\nabla \log _{10} Q_{t}$ and the $\nabla \sigma_{t}$ series.

This function is similar to a traditional rating curve but it incorporates a delay time, indicating that the time series are not perfectly out of phase, and it illustrates the importance of preceding conductivity (which in turn is dependent upon past discharge) in addition to discharge variation in estimating current conductivity levels. Reference to Figure 2 confirms that, where diurnal cycles of discharge and electrical conductivity are clearly defined, the two variables are indeed not perfectly out of phase but, in all but one of the diurnal cycles, the peak of electrical conductivity falls on the rising limb of the discharge hydrograph.

The present authors have previously suggested that this pattern may be explained in terms of routing and storage effects superimposed upon the mixing of water from "englacial" and "subglacial" source areas (Gurnell and Fenn, 1984[b]). The conduit system of the glacier may be regarded as a temporary reservoir in which mixing and enrichment of waters may take place. The peaking of electrical conductivity on the rising limb of the diurnal discharge hydrograph may be explained by the evacuation of waters of relatively high conductivity, held in the conduit system during low flows, in advance of the diurnal input of freshly ablated waters. The conduit system of most glaciers probably incorporates subsystems possessing distinctive routing characteristics: Campbell and Rasmussen (1973), for example, suggested that most glaciers probably have multiple transport waves migrating through them at any time. In many glaciers these subsystems do not merge within the glacier but emerge at separate portal streams which mix at some distance from the snout in the pro-glacial zone. In such cases, surveys of the quantity-quality characteristics of tributary outflows may provide valuable insights into the 
nature and performance of the hydrological system of the glacier, and may provide a useful means of interpreting the quantity-quality characteristics of post-mixing bulk melt waters. The results of such a survey follow. It is also noteworthy that the marked diurnal cycles of Figure 4, which were also present in the autocorrelation functions for the two individual time series, suggest that, if less frequent sampling were required to identify longer-term patterns, then a $24 \mathrm{~h}$ sampling interval would be adequate.

\section{Spatial sampling: 1 h sampling interval}

Figure 5 presents the results of sampling electrical conductivity and suspended-sediment concentration on the three main tributary streams issuing from the snout of glacier de Tsidjiore Nouve (sites 7, 8, and 9) and on the main stream (site 1) during four separate $12 \mathrm{~h}$ periods in July 1981. Several properties of the spatial pattern in electrical conductivity can be identified from Figure 5:

(1) The tributary and main-stream sites exhibited decreasing electrical conductivity during the day as discharge increased. In some cases there was a slight increase in conductivity early in the sampling period before the general decrease. Minimum discharge in the main stream occurred at $7.00 \mathrm{~h}$ on 2 July and at $8.00 \mathrm{~h}$ on the other three days, while the peak of electrical conductivity occurred up to two hours after the discharge minimum in the main stream (site 1). This lag corresponds well with the $2 \mathrm{~h}$ lag of the
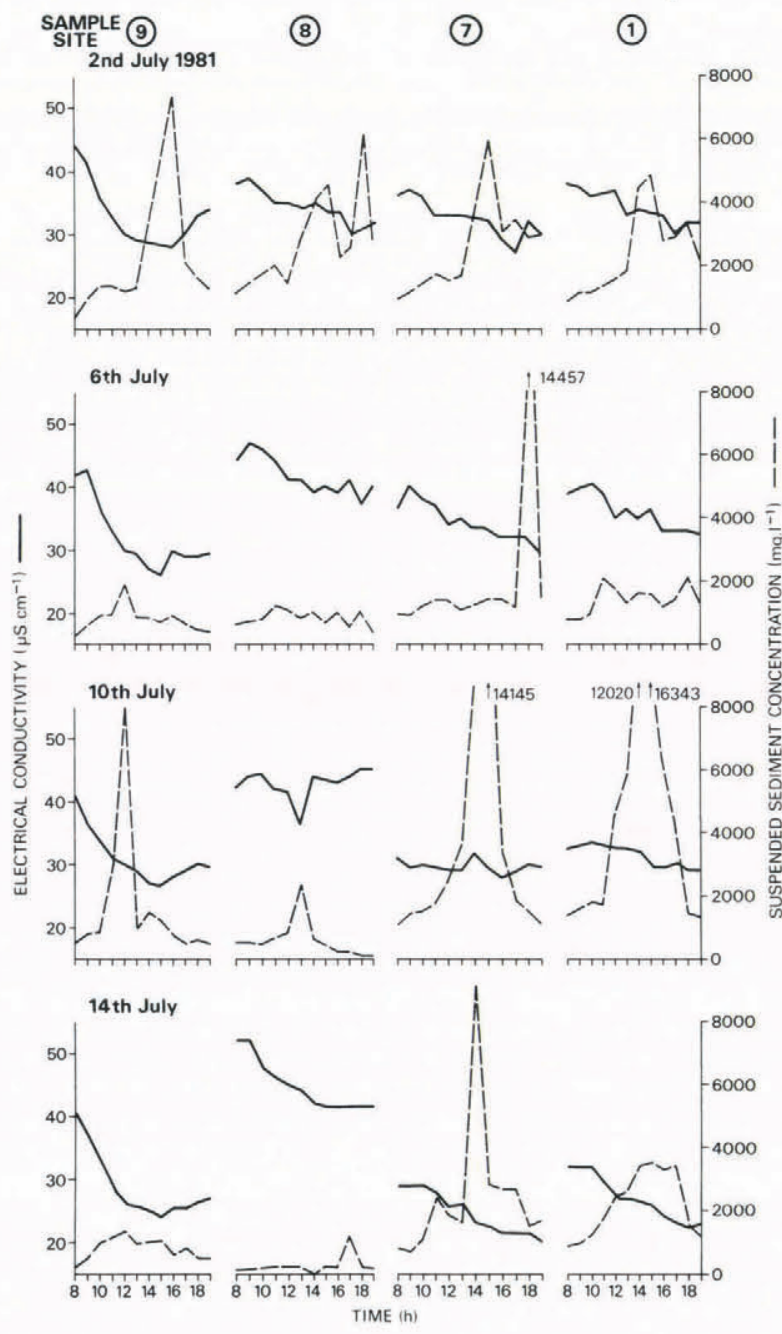

Fig. 5. Hourly observations of electrical conductivity and suspended-sediment concentration at sites $1,7,8$, and 9 over four $12 \mathrm{~h}$ periods, July 1981. cross-correlation function of Figure 4. The three tributaries achieved an electrical conductivity maximum at lags ranging from $0 \mathrm{~h}$ to $2 \mathrm{~h}$ after the main-stream discharge minimum and at leads ranging from $0 \mathrm{~h}$ to $2 \mathrm{~h}$ before the main-stream conductivity maximum. A maximum difference of $2 \mathrm{~h}$ was observed between the timing of peak conductivity at the four sites during the four days. The general decline in electrical conductivity at all of the four sites during the $12 \mathrm{~h}$ periods was consistent with the timing of the falling component of the diurnal conductivity cycles identified at the water intake over a much longer sampling period, as discussed in the preceding section.

(2) The electrical conductivity at site 1 was an approximate average of the concurrent conductivity of the tributaries and was virtually identical to simultaneous observations at sites 2 and 3 . This suggests good mixing of water from the tributaries. There was also an apparent trend during the four days of generally increasing conductivity at site 8 and decreasing conductivity at sites 7 and 9 , leading to an overall decrease in conductivity at site 1 .

(3) An interesting detail of Figure 5 is the low in conductivity on tributary 8 at $13.00 \mathrm{~h}$ on $10 \mathrm{July}$, followed by a conductivity high on tributary 7 at $14.00 \mathrm{~h}$ on the same day. A sudden increase of $14 \%$ in the main-stream discharge at $15.00 \mathrm{~h}$ on the same day was caused by a sudden outburst of water in tributary 7. Figure 5 shows that this outburst was accompanied by an enormous increase in suspended-sediment concentration in tributary 7 , from less than $4000 \mathrm{mg} 1^{-1}$ at $13.00 \mathrm{~h}$ to over $14000 \mathrm{mg} \mathrm{l}^{-1}$ at $15.00 \mathrm{~h}$

These observations of conductivity variations at four sites show that there are marked differences in conductivity between sites within individual days, but that the diurnal cycles of conductivity observed on the main stream have very similar timing to those in the tributaries. It appears, therefore, that measurements of conductivity taken nearly simultaneously at separate sites form an accurate basis for identifying spatial variations in conductivity in the stream system. The data presented in this section have shown the nature of the spatia patterns in conductivity that occur over an hourly time-scale. As noted earlier, measurements of conductivity taken at $24 \mathrm{~h}$ intervals yield data which are largely independent of diurnal variation and so may be used to identify longer-term patterns. Such patterns are described in the next section.

\section{Spatial sampling: $24 h$ and $48 h$ sampling interval}

Figures 6 and 7 show spatial patterns in electrical conductivity on a one-day sampling interval in July 1978 and a two-day sampling interval in July 1981. Site 11 (sampled in 1981) was the only site entirely supplied by ground water from a spring in the old lateral moraine bordering the pro-glacial stream, although site 6 had no overland contribution of flow from the glacier after 6 July in the 1981 study period. Several characteristics of Figures 6 and 7 are noteworthy:

(1) There was an inverse relationship between electrical conductivity and discharge in the main stream (site 1 and the main monitoring station).

(2) The tributary sampling sites, apart from site 11 , showed great similarity in their electrical conductivity during periods of high discharge (for example 17 to 30 July 1978 and 6 to 16 July 1981), and showed considerable differences in their electrical conductivity at times of low discharge (for example 1 to $13 \mathrm{July}$ 1978 and 19 to 28 July 1981).

(3) Site 11 exhibited the highest electrical conductivity measured and may be taken to provide an indication of the electrical conductivity of long residence time, "subglacial" water in the remaining tributaries. 


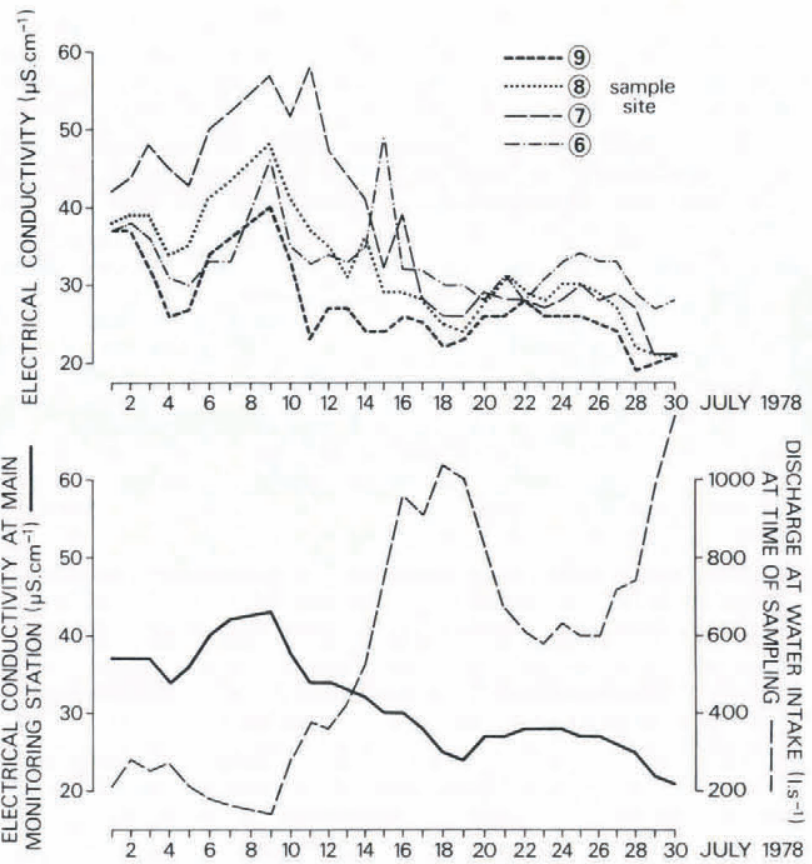

Fig. 6. Spatial patterns of electrical conductivity on a one-day sampling interval, July 1978.

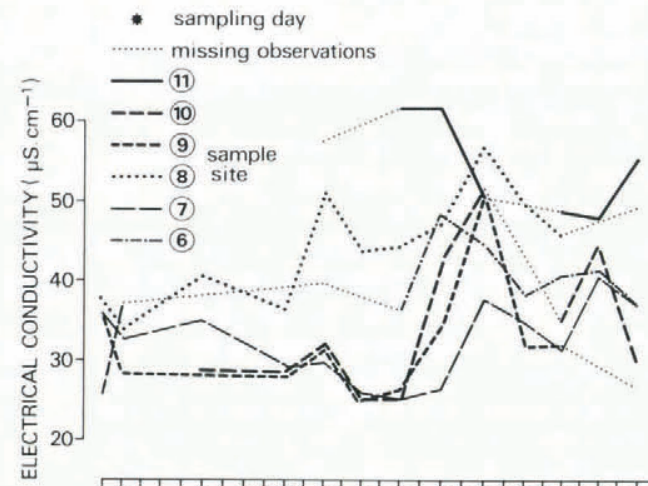

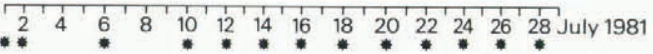

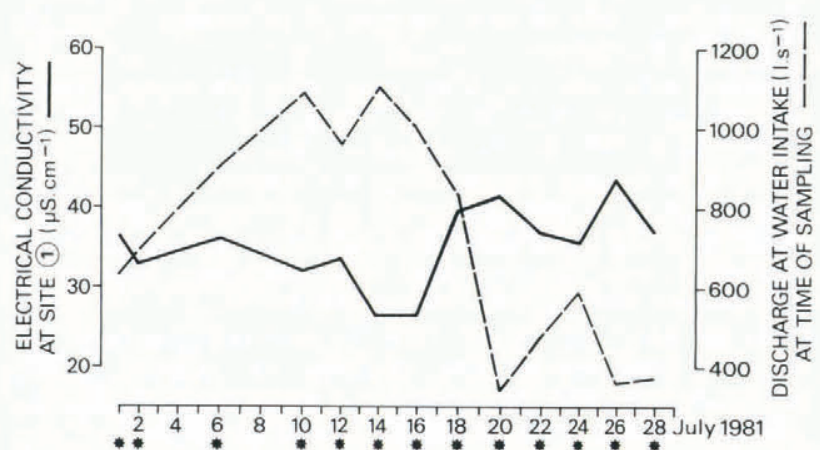

Fig. 7. Spatial patterns of electrical conductivity on a two-day sampling interval, July 1981.

(4) Assuming that the electrical conductivity at each sampling site reflects the proportion of the flow contributed by "englacial" and "subglacial" flow contributions of approximately constant conductivity (as defined by Collins, 1979), then there appear to be substantial changes in these proportions in different tributaries within and between ablation seasons, since the electrical conductivity of the mixed water from these source areas did not remain constant at each sampling site. For example, there was a progressive divergence in conductivity between sites 8 and 6 and sites 7,9 , and 10 during July 1981 , particularly up to 16 July. In addition, the relative magnitude of electrical conductivity in the three main tributaries changed from $7>8>9$ in 1978 to $8>9>7$ in 1981. This inter-seasonal change cannot be explained simply by adjustments in tributary discharge using a simple mixing model, because tributary 7 carried by far the most water throughout July 1978 and after 9 July 1981. In addition, in both years all of the supraglacial streams draining across the snout of the glacier contributed to the flow in tributary 7 .

\section{SUMMARY, DISCUSSION, AND CONCLUSIONS}

Analyses of hourly instantaneous observations of electrical conductivity and discharge at the water intake, and hourly spatial sampling over $12 \mathrm{~h}$ periods, indicated that diurnal cycles were present in the data and that cycles in electrical conductivity occurred with approximately the same timing throughout the pro-glacial stream network. From this it was concluded that simultaneous sampling every $24 \mathrm{~h}$ would be adequate to identify longer-term temporal patterns in electrical conductivity.

Information from all temporal scales indicated an approximate inverse relationship between electrical conductivity and discharge, but detailed analysis of over 50 days of hourly observations of the two variables showed that the relationship was not perfectly inverse. Diurnal cycles existed in both series, although these were slightly different in form between the two series. The cross-correlation function between the first differenced electrical conductivity and the $\log _{10}$ transformed discharge series showed that the two series were not perfectly out of phase, but that, on average, this could be achieved by lagging the discharge forward by two hours.

Spatial observations of electrical conductivity on tributaries to the main pro-glacial stream in July 1978 and July 1981 showed that there was no simple relationship between levels of conductivity in the tributaries and in the main stream. Although the electrical conductivity of the main stream was always near the centre of the range of concurrent electrical conductivity in the tributaries, complementary shifts in tributary conductivity could be identified between seasons, between days, and for a short period within one of the days of $12 \mathrm{~h}$ spatial sampling. These shifts were usually gradual and, if electrical conductivity represents the mixing of "englacial" and "subglacial" flow components of roughly constant conductivity, then these changes can be interpreted in terms of the gradual rerouting of one or both of these components before reaching the snout of the glacier. The gradual decrease in electrical conductivity in tributaries 7 and 9 , and the concurrent increase in electrical conductivity of tributary 7 during July 1981 , could be explained by rerouting of the "englacial" flow component. This hypothesis is reinforced by the fact that during this period a clear increase in discharge was observed in tributary 7 relative to flow in the other tributaries. Moreover, the abrupt complementary changes in conductivity in tributaries 7 and 8 during 10 July 1981, and the observed sudden increase in discharge and suspended-sediment concentration in tributary 7 , could be explained by a rapid form of the same mechanism; a sudden rerouting of "englacial" water from one tributary to the other. The less sudden observed decrease in discharge in tributary 8 on the same day and the sudden increase in tributary 7 could be explained by temporary storage of some of the water during this rerouting. Finally, there was a major decrease in the electrical conductivity of tributary 7 between 1978 and 1981 in spite of the fact that this was the tributary with the highest discharge for almost all of the observation period in both years. The "englacial"-"subglacial" mixing model would suggest that this change resulted from a shift in the drainage pattern of "subglacial" water, since variations in only the "englacial" component for a 
tributary with the highest discharge in both years could not explain such a major change in electrical conductivity level relative to the levels in other tributaries.

The simple two-reservoir mixing model forms a useful context in which to interpret the observations of electrical conductivity under discussion. The temporal electrical conductivity patterns in tributary streams draining the snout of glacier de Tsidjiore Nouve are not identical with the pattern exhibited in the main stream, and, under the two-reservoir model, these differences may be explained in terms of spatial and temporal variations in the storage and routing of melt-water drainage from the glacier. It seems likely that the form and size of the area of the glacier contributing to discharge in each tributary varies greatly over time and is not confined to variations in the source areas of water of low electrical conductivity ("englacial" water). The variation in contributing area will influence both the amount and the proportions of water from "englacial" and "subglacial" source areas mixing in the flow of the tributaries and also the potential drainage routes to each tributary. These factors clearly exert major controls on the electrical conductivity of the water in each tributary. The authors believe that the temporal variations in the size and location of "englacial" and "subglacial" source areas feeding each tributary provide the primary explanation of the observed patterns in electrical conductivity. Nevertheless, it is accepted that component flow contributions are unlikely to display absolutely constant electrical conductivity and it is clear that variations in the conductivity, as well as the discharge, of waters from different source areas would generate variations in outflow conductivity. Modification of the conductivity characteristics of waters during transit to the outflow streams would have similar effects. It is accepted that the operation of effects other than those proposed in the explanations given here may well be partially responsible for generating the patterns in conductivity observed in the pro-glacial stream system. In fact, the authors are convinced that residence time and routing of flows through the glacier have effects on the observed electrical conductivity and that the main conduit system within the glacier may usefully be considered to be a third reservoir where mixing and enrichment of the water may take place (Gurnell and Fenn, 1984[b]). Nevertheless, they believe these effects to be of only secondary importance in controlling the observed pattern of electrical conductivity in the pro-glacial stream network to the primary control of the mixing of "englacial" and "subglacial" flow components of very different conductivity. Such a view would appear to conform to that of Raiswell (1984).

\section{ACKNOWLEDGEMENTS}

This research was undertaken while one of the authors (C.R.F.) was in receipt of a United Kingdom Natural Environment Research Council research studentship. Grande Dixence S.A., particularly Ingrs Bezinge, Dayer, Arlettaz, and Mudry, are gratefully acknowledged for the provision of discharge data and field assistance. Dr J. Gurnell and Mr C. MarMolinero gave very helpful criticisms of an early version of the manuscript.

\section{REFERENCES}

Behrens, H., and others. 1971. Study of the discharge of alpine glaciers by means of environmental isotopes and dye tracers, by $\mathrm{H}$. Behrens [and 7 others]. Zeitschrift für Gletscherkunde und Glazialgeologie, Bd. 7, Ht. 1-2, p. 79-102.
Box, G.E.P., and Jenkins, G.M. 1970. Time series analysis, forecasting and control. San Francisco, Holden-Day.

Campbell, W.J., and Rasmussen, L.A. 1973. The production, flow and distribution of melt water in a glacier treated as a porous medium. Union Géodésique et Géophysique Internationale. Association Internationale d'Hydrologie Scientifique. Commission de Neiges et Glaces. Symposium on the Hydrology of Glaciers, Cambridge, 7-13 September 1969, p. 11-27. (Publication No. 95 de l'Association Internationale d'Hydrologie Scientifique.)

Collins, D.N. 1979. Quantitative determination of the subglacial hydrology of two Alpine glaciers. Journal of Glaciology, Vol. 23, No. 89, p. 347-62.

Fahnestock, R.K. 1963. Morphology and hydrology of a glacial stream, White river, Mount Rainier, Washington. United States Geological Survey. Professional Paper 422-A.

Gurnell, A.M. 1982. The dynamics of suspended sediment concentration in an Alpine pro-glacial stream network. (In Hydrological aspects of aipine and high mountain areas. Proceedings of the Exeter Symposium, July 1982. International Association of Hydrological Sciences Publication No. 138, p. 319-30.)

Gurnell, A.M., and Fenn, C.R. 1984[a]. Box-Jenkins transfer function models applied to suspended sediment concentration - discharge relationships in a proglacial stream. Arctic and Alpine Research, Vol. 16, No. 1, p. 93-106.

Gurnell, A.M., and Fenn, C.R. 1984[b]. Flow separation, sediment source areas and suspended sedimer.t transport in a proglacial stream. Catena Supplement 5, p. 109-19.

Lemmens, M. 1978. Relations entre concentration en cations dissous et débit de l'émissaire du glacier de Tsijiore Nouve (Valais). Catena (Braunschweig), Vol. 5, Nos. 3-4, p. 227-36.

Lemmens, M., and Roger, M. 1978. Influence of ion exchange on dissolved load of Alpine meltwaters. Earth Surface Processes, Vol. 3, No. 2, p. 179-87.

Metcalf, R.C. 1979. Energy dissipation during subglacial abrasion of Nisqually Glacier, Washington, U.S.A. Journal of Glaciology, Vol. 23, No. 89, p. 233-46.

Ostrem, G. [ $\left.{ }^{\mathrm{c}} 1975.\right]$ Sediment transport in glacial meltwater streams. (In Jopling, A.V., and McDonald, B.C., ed. Glaciofluvial and glaciolacustrine sedimentation. Tulsa, Oklahoma, Society of Economic Paleontologists and Mineralogists, p. 101-22. (Special Publication No. 23.))

Raiswell, R. 1984. Chemical models of solute acquisition in glacial melt waters. Journal of Glaciology, Vol. 30, No. 104 , p. $49-57$.

Souchez, R.A., and Lorrain, R.D. 1975. Chemical sorting effect at the base of an Alpine glacier. Journal of Glaciology, Vol. 14, No. 71, p. 261-65.

Souchez, R.A., and others. 1973. Ref reezing of interstitial water in a subglacial cavity of an Alpine glacier as indicated by the chemical composition of ice, by R.A. Souchez, R.D. Lorrain, and M.M. Lemmens. Journal of Glaciology, Vol. 12, No. 66, p. 453-59.

Souchez, R.A., and others. 1978. Pressure-melting within a glacier indicated by the chemistry of re-gelation ice, by R.A. Souchez, M. Lemmens, R. Lorrain, and J.-L. Tison. Nature, Vol. 273, (No. 5662), p. 454-56.

Vivian, R.A., and Zumstein, J. 1973. Hydrologie sous-glaciaire au glacier d'Argentière (Mont-Blanc, France). Union Géodésique et Géophysique Internationale. Association Internationale d'Hydrologie Scientifique. Commission de Neiges et Glaces. Symposium on the Hydrology of Glaciers, Cambridge, 7-13 September 1969, p. 53-64. (Publication No. 95 de l'Association Internationale d'Hydrologie Scientifique.) 